\title{
PENGARUH PERENCANAAN, KAPASITAS SUMBER DAYA MANUSIA DAN KOMITMEN ORGANISASI TERHADAP PENYERAPAN ANGGARAN BELANJA DAERAH PADA PEMERINTAH KABUPATEN KEPULAUAN TALAUD
}

\author{
Deiby Isilda Alumbida, David P.E. Saerang, Ventje Ilat \\ (email: deibyisilda@gmail.com)
}

\begin{abstract}
The absorption of the budget is a very important part in the Government's financial management both central government or local governments, it is because the level of absorption of the budget can be used as an indicator of the extent of the commitment of the Government apparatus to manage the budget in accordance with the planning. Budgets which are absorbed based on planning will provide the maximum benefit to the good economy, is erabled encourage the improvement of welfare for the area which is one of the nation's national goal of Indonesia. This research was conducted in the Talaud Islands Regency with the purpose of analyzing the influence of planning, capacity of human resources and organizational commitment toward regional budget absorption rate either simultaneously or partial. This research uses 3 independent variables consist of Planning $\left(X_{1}\right)$, Human Resource Capacity $\left(X_{2}\right)$, Organizational Commitment $\left(X_{3}\right)$ the dependent variable is the Absorption Of The Budget (Y). Data analysis was endured by using multiple linear regression analysis. The results indicates that the planning, capacity of human resources and organizational commitment affect the absorption of the regional budget of Talaud Islands Regency Government. However, only partially significantly influence planning while the capacity of the human resources and the commitment do not significantly influence the absorption of budget. Multiple linear regression analysis results show the planning, human resource capacity and commitment of the organization have a positive effect to the absorption of the budget. While the results of the analysis show that the determination of the coefficient of $36.2 \%$ absorption rate is affected by the budget planning, capacity of human resources and organizational commitment onthe other hard $63.8 \%$ absorption rate is influenced by other variables which are not included in this research.
\end{abstract}

Keywords : Teori Institusional, Teori Pengabdian, Social Learning Theory

\section{PENDAHULUAN}

Salah satu tujuan nasional bangsa dan negara Indonesia yang tercantum dalam pembukaan Undang-Undang Dasar (UUD) 1945 alinea ke empat adalah memajukan kesejahteraan umum. Sebagai upaya untuk mempercepat peningkatan kesejahteraan rakyat dalam rangka mewujudkan tujuan nasional tersebut, pemerintah pusat melakukan kebijakan desentralisasi dimana sebagian wewenangnya diserahkan kepada daerah otonom untuk mengatur dan mengurus urusan pemerintahan dalam kerangka Negara Kesatuan Republik Indonesia. Sebagai konsekuensinya, pemerintah memerlukan pendanaan memadai yang dianggarkan melalui Anggaran Pendapatan dan Belanja Negara/Daerah (APBN/APBD), dan pada saatnya harus dikeluarkan melalui Kas Negara/Kas Daerah.

Kebijakan desentralisasi di Indonesia pertama kali digulirkan pada akhir tahun 1999 dengan dikeluarkannya Undang-Undang (UU) No. 22 Tahun 1999 tentang Pemerintahan daerah yang lebih dikenal dengan undang-undang otonomi daerah. Namun meski telah ditetapkan sejak tahun 1999, UU ini baru berlaku efektif ditahun 2001. Secara umum, desentralisasi diartikan sebagai pelimpahan kewenangan oleh pemerintah pusat kepada pemerintah daerah yang ada dalam wilayahnya, salah satunya adalah desentralisasi fiskal dimana tiap daerah diberi keleluasaan untuk mengelolah keuangannya masing-masing. Desentralisasi fiskal pada dasarnya dapat mendorong peningkatan efisiensi belanja karena 
Pemerintah daerah lebih tahu kebutuhan masyarakatnya daripada Pemerintah Pusat. Komitmen pemerintah pusat dalam menerapkan desentralisasi fiskal makin nampak, hal ini terlihat dari peningkatan dana transfer setiap tahun. Namun pada saat pemerintah pusat terus berupaya untuk menjalankan komitmen dalam menerapkan desentralisasi fiskal dengan meningkatkan dana transfer ke daerah disetiap tahun anggaran, sebuah fenomena yang menarik justru terjadi di daerah-daerah, yaitu minimnya realisasi penyerapan Anggaran Pendapatan dan Belanja Daerah (APBD) di sebagian besar daerah wilayah Negara Kesatuan Republik Indonesia (NKRI).

Sejak dimekarkan dari Kabupaten Sangihe pada tanggal 2 Juli 2002 yang ditetapkan melalui UU No. 8 Tahun 2002, Kabupaten Talaud tidak terlepas dari persoalan realisasi anggaran. Dalam sistem penganggaran berbasis kinerja minimnya penyerapan anggaran memang tidak dapat dijadikan sebagai indikator buruknya kinerja birokrasi, akan tetapi kondisi perekonomian saat ini masih sangat bergantung pada konsumsi pemerintah, sehingga belanja pemerintah turut menjadi salah satu penggerak roda perekonomian di daerah yang pada akhirnya mendorong terciptanya multiplier effect bagi daerah tersebut sehingga mampu meningkatkan kesejahteraan bagi masyarakatnya dalam hal ini pada Kabupaten Kepulauan Talaud. Selain itu, adanya dana yang tidak terserap hingga diakhir tahun anggaran menunjukan adanya inkonsistensi antara perencanaan anggaran dan realisasi. Meskipun dana tersebut dapat dimanfaatkan kembali pada tahun anggaran berikutnya, tetapi berdasarkan konsep time value of money dana tersebut berpotensi berkurang atau bahkan kehilangan manfaat belanja yang semestinya dapat dimanfaatkan untuk sebesar-besarnya kemakmuran masyarakat.

\section{TINJAUAN PUSTAKA}

\section{Teori Institusional}

Teori institusionalisme merupakan sebuah teori yang berangkat dari konsep-konsep dalam Sosiologi yang menjelaskan bagaimana dinamika yang terjadi di dalam sebuah organisasi yang terdiri dari sekumpulan manusia. Teori ini berasal dari para ahli filosof yunani yang telah menyadari adanya keterkaitan antarinstitusi. Pada abad ke 19-an Max Weber mencoba mengkaji birokrasi dan institusi secara sistematis. Weber melihat bahwa politik sebagai hal yang berkaitan dengan penyelenggaraan negara. John W. Meyer dan Brian Rowan (1977) menulis "banyak posisi, kebijakan, program dan prosedur organisasi modern dipengaruhi oleh opini publik, pandangan konstituen, pengetahuan sah melalui sistem pendidikan, prestise sosial, hukum, dan pengadilan. Paul J. Di Maggio dan Walter W. Powell (1983) berargumen bahwa teori institusional mengkritik teori ekonomi dan kontingensi yang sangat rasional, yaitu menjelaskan struktur dan fungsi organisasi dengan ukuran efisiensi. Sementara W. Richard Scott dalam rotich (2015) menjelaskan bahwa fokus teori institusional adalah mempertimbangkan proses di mana struktur yang meliputi skema, aturan, norma, dan rutinitas sebagai panduan untuk berperilaku. Jadi menurut beberapa pandangan tersebut pada intinya teori institusional menjelaskan bahwa kebijakan atau keputusan yang diambil oleh organisasi akan dipengaruhi oleh berbagai tekanan maupun kepentingan konstituen sekaligus sebagai stakeholder yang berlandaskan pada aspek sosial, hukum dan disiplin ilmu yang berkaitan dengan kebijakan tersebut. Teori institusional merupakan teori yang sangat relevan untuk memahami organisasi sektor publik (Bealing, et al. dalam Juliani 2014).

\section{Stewardship Theory (Teori Pengabdian)}

Teori Stewardship menurut Donaldson \& Davis dalam Raharjo (2010), mempunyai akar psikologi dan sosiologi yang didesain untuk menjelaskan situasi dimana manajer sebagai steward akan bertindak sesuai kepentingan principal (pemilik). Teori stewarship merupakan teori yang menggambarkan situasi dimana para manajer tidaklah termotivasi oleh tujuantujuan individu tetapi lebih ditujukan pada sasaran hasil utama mereka untuk kepentingan 
organisasi. Teori ini memandang manajemen sebagai pihak yang mampu melaksanakan tindakan yang sebaik-baiknya ditujukan untuk memenuhi kebutuhan stakeholders. Konsep teori ini didasarkan pada asas kepercayaan kepada pihak yang diberikan wewenang, dimana manajemen dalam suatu organisasi dipandang sebagai good steward yang melaksanakan tugas yang diberikan oleh atasannya secara penuh tanggung jawab.

Sehingga dapat disimpulkan bahwa teori stewardship adalah teori yang mengambarkan hubungan yang harmonis antara stakeholders dan manajemen dimana stakeholders memberikan kepercayaan penuh kepada manajemen dalam menjalankan tugas dan mengelola seluruh sumber daya yang ada, sebaliknya dari pihak manajemen mampu melaksanakan tugas dan mengelola seluruh sumber daya yang dipercayakan kepadanya dengan penuh tanggungjawab tanpa mengutamakan kepentingan pribadi tetapi berfokus kepada kepentingan bersama.

\section{Social Learning Theory}

Social Learning Theory merupakan gagasan dari Albert Badura sejak tahun 1960an. Teori ini adalah pengembangan dari teori behaviorisme yang digagas oleh Burhuss Frederic Skinner pada tahun 1930, yang secara luas dikenal dengan teori operant conditioning. Teori pembelajaran sosial/ social learning theory mengungkapkan bahwa individu dapat belajar melalui pengamatan dan pengalaman langsung. Setiap perubahan perilaku yang relatif permanen sebagai hasil dari pengalaman. Teori ini berasumsi bahwa perilaku merupakan fungsi dari konsekuensi, juga mengakui keberadaan pembelanjaran melalui pengamatan dan pentingnya persepsi dalam pembelajaran.

Albert Bandura adalah salah seorang behavioris yang menambahkan aspek kognitif terhadap behaviorisme. Teori belajar sosial Bandura tentang kepribadian didasarkan kepada formula bahwa tingkah laku manusia merupakan hasil interaksi timbal balik yang terus menerus antara faktor-faktor penentu internal (kognisi, persepsi, dan faktor lainnya yang mempengaruhi kegiatan manusia), dan eksternal (lingkungan), proses ini disebut reciprocal determinism. Namun disisi lain, Badura Bandura menyetujui keyakinan dasar behaviorisme yang mempercayai bahwa kepribadian dibentuk melalui belajar. Sejalan dengan pandangan Badura, Mathis (2010:5) menyebutkan "Human capital is the collective value of the capabilities, knowledge, skills, life experiences, and motivation of an organizational workforce”. Sehingga dapat disimpulkan bahwa kemampuan atau kapasitas seseorang tidak hanya lahir dari kecerdasan intelektualnya saja tetapi juga melalui proses reciprocal determinism (determinis resiprokal atau konsep yang saling mempengaruhi) yang menghasilkan pengalaman, keterampilan yang didasari oleh kemauan untuk belajar serta motivasi seseorang untuk melakukan pekerjaan agar memberikan hasil yang maksimal.

\section{Kerangka Konseptual Penelitian}

Pada lingkup perekonomian daerah, konsumsi pemerintah daerah merupakan salah satu komponen yang menentukan nilai produk domestik regional bruto (PDRB), sehingga dapat dipastikan bahwa konsumsi pemerintah daerah turut mempengaruhi pertumbuhan ekonomi daerah tersebut. Besaran konsumsi pemerintah, tergantung besarnya anggaran yang ditetapkan pada tahapan perencanaan, dan sejauh mana konsistensi dalam merealisasikan perencanaan sebagaimana tercantum pada Dokumen pelaksanaan anggaran pada instansi masing-masing yang disebut DPA-SKPD.

Pelaksanaan kegiatan yang sesuai dengan perencanaan akan berimplikasi pada penyerapan anggaran daerah, namun disisi lain, aparatur pemerintah sebagai sumber daya manusia yang terlibat dalam perencanaan anggaran sekaligus sebagai pelaksana anggaran tersebut dituntut untuk memiliki kemampuan atau kapasitas yang memadai. Sebab kualitas perencanaan anggaran ditetukan oleh kualitas sumber daya yang terlibat dalam proses perencanaan tersebut, selanjutnya sejauh mana perencanaan tersebut dapat terealisasi semua bergantung pada tingkat komitmen organisasi pemerintah selaku pengelola anggaran tersebut 
dan kapasitas sumber daya manusia yang terlibat didalamnya, sehingga dapat disimpulkan bahwa keberhasilan pengelolaan keuangan daerah dimulai dari tahap perencanaan yang terintegrasi hingga tahap pelaksanaan anggaran yang terukur oleh tingkat penyerapan anggaran tersebut hingga berimplikasi pada peningkatan kesejateraan masyarakat selaku principal (pemilik) anggaran daerah.

Berdasarkan rumusan masalah dan landasan teori yang telah diuraikan pada bab sebelumnya, maka penulis mengembangkan kerangka pemikiran teoritis yang mendasari penelitian ini seperti Pada Gambar 3.1 untuk mendeskripsikan alur pemikiran yang mendasari penelitian ini. Pada model atau kerangka pemikiran terlihat adanya pengaruh langsung antara variabel independen $(\mathrm{X})$ terhadap Variabel dependen (Y).

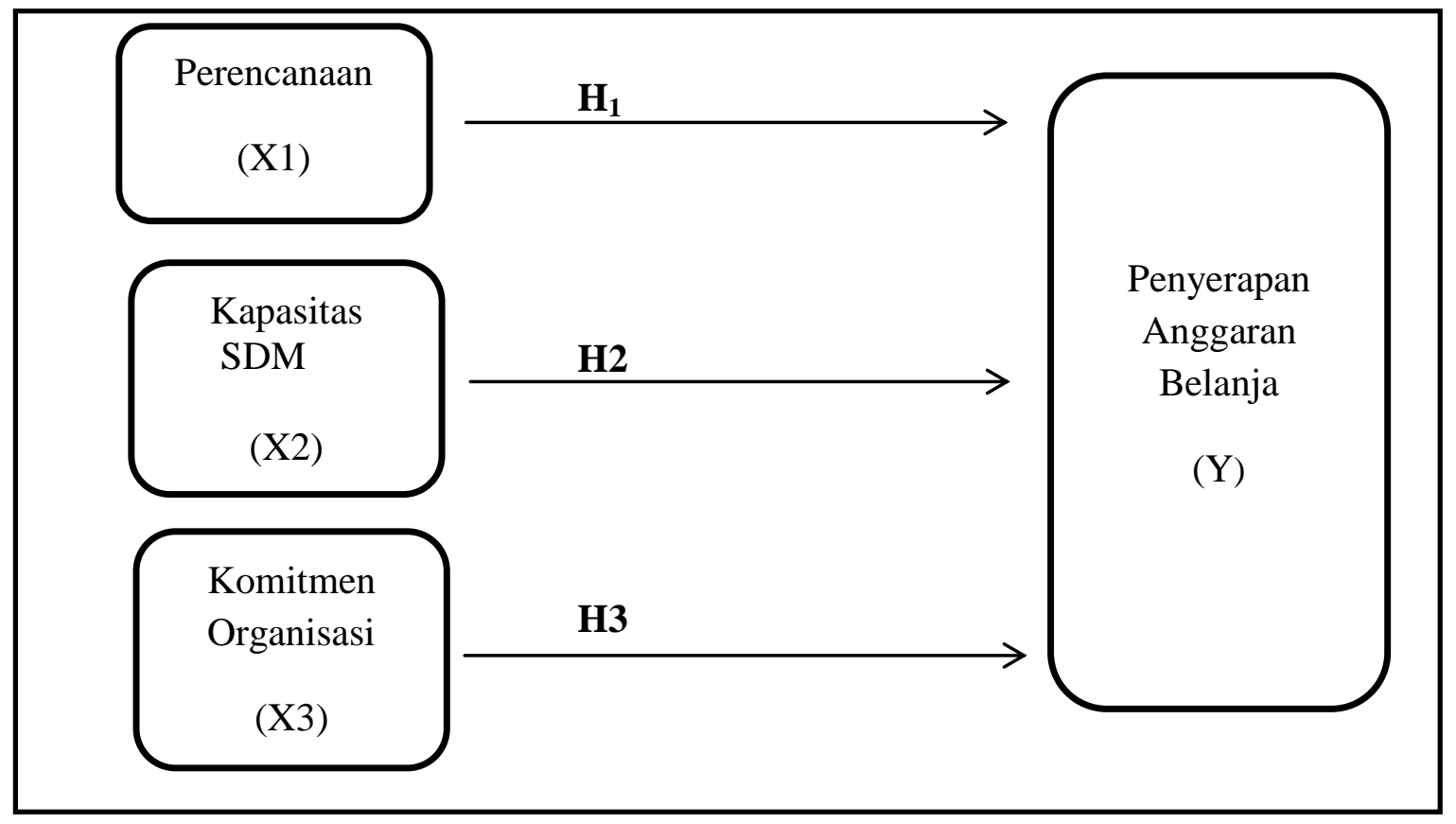

Gambar 3.1 Kerangka Konseptual

\section{HIPOTESIS}

Berdasarkan permasalahan yang telah dikemukakan sebelumnya dan kerangka konseptual, maka dapat dirumuskan hipotesis sebagai berikut.

\section{Pengaruh Perencanaan terhadap Penyerapan Anggaran Belanja Daerah}

UU No. 25 Tahun 2004 Pasal 1 ayat (1) mendefinisikan perencanaan sebagai suatu proses untuk menentukan tindakan masa depan yang tepat, melalui urutan pilihan dengan memperhitungkan sumber daya yang tersedia. Dalam siklus pengelolaan keuangan daerah, perencanaan berintegrasi dengan penganggaran sebab output dari perencanaan adalah DPA yang menjadi dasar pelaksanaan seluruh kegiatan selama tahun anggaran, sehingga keberhasilan pengelolaan keuangan daerah dimulai dari tahapan perencanaan.

Arif (2013) menyatakan kegagalan dalam perencanaan penganggaran akan berdampak pada tidak berjalannya program kerja pemerintah yang secara tidak langsung tentunya akan berdampak buruk terhadap kinerja pemerintah. Senada dengan itu, penelitian Priatno (2013) juga menemukan Perencanaan berpengaruh signifikan terhadap penyerapan anggaran pada Satuan Kerja lingkup pembayaran KPPN Blitar. Sementara itu, penelitian Ulfa (2013) menemukan bahwa perencanaan anggaran yang belum dilakukan sesuai dengan prinsip perencanaan anggaran yang baik mengakibatkan keterlambatan pengesahan anggaran, sehingga menghambat penyerapan anggaran pada Sekretariat DPRD DKI Jakarta T.A 2010 
dan 2011. Zarinah (2015) juga menemukan bahwa perencanaan berpengaruh terhadap tingkat penyerapan anggaran SKPD di Kabupaten Aceh Utara.

Perencanaan dapat dikatakan sebagai tahapan yang paling krusial dalam konteks pengelolaan keuangan daerah, sebab seluruh kegiatan yang perumusan program di dalam perencanaan pada akhirnya berimplikasi pada besarnya kebutuhan anggaran yang harus disediakan, sehingga keberhasilan penggunaan anggaran dimulai dari perencanaannya (Nugroho, 2015). Berdasarkan uraian teori dan penelitian sebelumnya, maka dirumuskan hipotesis ke 1 adalah sebagai berikut.

$\mathrm{H}_{1:}$ Perencanaan berpengaruh signifikan terhadap penyerapan anggaran belanja daerah.

Pengaruh Kapasitas Sumber Daya Manusia terhadap Penyerapan Anggaran Belanja Daerah

UU Nomor 22 tahun 1999 pasal 8 secara implisit menyebutkan bahwa "desentralisasi harus disertai dengan penyerahan dan pengalihan pembiayaan, sarana dan prasarana, serta sumber daya manusia”. Dengan kata lain sumber daya manusia adalah faktor determinan keberhasilan desentralisasi. Oleh karena itu Sumber Daya Manusia harus dikelola dengan baik untuk meningkatkan efektivitas dan efisiensi organisasi. Sumber Daya Manusia adalah rancangan sistem-sistem formal dalam sebuah organisasi untuk memastikan penggunaan bakat manusia secara efektif dan efisien guna mencapai tujuan organisasi (Mathis dan Jackson, 2006). Faktor kunci keberhasilan dalam pengelolaan anggaran adalah staf yang berpengalaman dan mempunyai motivasi. Sumber Daya Manusia (SDM) menjadi unsur utama dalam setiap aktivitas yang dilakukan. Kalaupun menggunakan peralatan yang canggih dan handal namun tanpa dibarengi peran aktif sumber daya manusia yang memadai, peralatan tersebut tidak akan bekerja secara maksimal (Zarinah, 2015).

Penelitian Herryanto (2012) menemukan bahwa minimnya kapasitas SDM merupakan salah satu faktor yang mempengaruhi keterlambatan penyerapan anggaran belanja pada satuan kerja kementrian/lembaga di wilayah Jakarta. Hal senada ditemukan dalam Penelitian Arif (2013) bahwa minimnya kapasitas SDM merupakan faktor penyebab minimnya penyerapan APBD T.A 2011 di Kabupaten Pelalawan Provinsi Riau. Penelitian Zarinah (2015) juga menemukan Kualitas Sumber Daya Manusia berpengaruh terhadap tingkat penyerapan anggaran SKPD di Kabupaten Aceh Utara. Hal berbeda ditemukan dalam penelitian Priatno (2013) dimana Sumber Daya Manusia berpengaruh tidak signifikan terhadap penyerapan anggaran pada satuan kerja lingkup pembayaran KPPN Blitar. Berdasarkan uraian teori dan penelitian sebelumnya, maka dirumuskan hipotesis ke 2 adalah sebagai berikut.

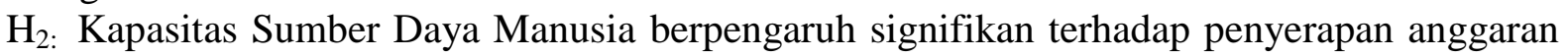
belanja daerah.

\section{Pengaruh Komitmen Organisasi terhadap Penyerapan Anggaran Belanja Daerah}

Stephen P. Robbins dan Timothy A. Judge dalam Rumenser (2014) mendefinisikan komitmen sebagai suatu keadaan dimana seorang individu memihak organisasi serta tujuantujuan dan keinginannya untuk mempertahankan keanggotaannya dalam organisasi. Komitmen merupakan seluruh upaya yang sinergi dari seluruh anggota organisasi itu sendiri dalam mewujudkan tujuan organisasinya sesuai dengan perencanaan yang telah disepakati. Sedangkan komitmen organisasi menurut Noe (2000) adalah tingkatan dimana seseorang memposisikan dirinya pada organisasi dan kemauan untuk melanjutkan upaya pencapaian kepentingan organisasinya. Yang dimaksud organisasi dalam penelitian ini adalah Satuan Kerja Perangkat Daerah sedangkan anggotanya merupakan Aparat Sipil Negara di daerah.

Penelitian Arif (2013) menemukan bahwa lemahnya komitmen organisasi merupakan salah satu faktor penyebab minimnya penyerapan APBD di Kota Dumai. Hal yang sama juga ditemukan dalam Penelitian Juliani (2014) dimana komitmen manajemen berpengaruh terhadap tingkat penyerapan anggaran belanja barang dan jasa pada pemerintah daerah 
Istimewa Yogyakarta. Dengan komitmen yang kuat akan memungkinkan setiap anggota memberdayakan seluruh kemampuan atau sumber daya yang dimilikinya, sebaliknya tanpa komitmen maka pekerjaan - pekerjaan besar akan sulit dilaksanakan. Berdasarkan uraian teori dan penelitian sebelumnya, maka dirumuskan hipotesis ke 3 adalah sebagai berikut. $\mathrm{H}_{3}$ : Komitmen organisasi berpengaruh signifikan terhadap penyerapan anggaran belanja daerah

\section{METODE PENELITIAN}

\section{Jenis Pendekatan Penelitian}

Ditinjau dari jenis data, penelitian ini menggunakan metode kuantitatif. Menurut Sugiyono, metode penelitian kuantitatif dapat diartikan sebagai metode penelitian yang berlandaskan pada filsafat positivisme, digunakan untuk meneliti pada populasi atau sampel tertentu, merupakan pola penelitian yang pengumpulan data menggunakan instrumen penelitian, analisis data bersifat kuantitatif/statistik dengan tujuan untuk menguji hipotesis yang telah ditetapkan. Dilihat dari hubungan antar variabel, penelitian ini merupakan penelitian korelasi. Penelitian korelasi juga sering disebut penelitian sebab akibat dengan tujuan untuk mengetahui hubungan antar variabel bebas dengan variabel terikat. Dimana yang menjadi variabel bebas dalam penelitian ini adalah variabel Perencanaan $\left(\mathrm{X}_{1}\right)$, variabel Kapasitas Sumber Daya Manusia $\left(\mathrm{X}_{2}\right)$ dan Komitmen Organisasi $\left(\mathrm{X}_{3}\right)$ dan yang menjadi variabel terikat adalah Penyerapan Anggaran Belanja (Y).

\section{Data}

Berdasarkan sumbernya, data yang digunakan dalam penelitian ini adalah data primer dan data sekunder.

a. Dalam penelitian ini, data primer diperoleh dengan teknik penyebaran kuesioner pada SKPD di Kabupaten Kepulauan Talaud. Kuesioner yang dimaksud merupakan daftar pertanyaan yang harus dijawab oleh responden yang merupakan sampel dari penelitian.

b. Dalam penelitian ini, data sekunder diperoleh dari berbagai sumber seperti bukubuku, Produk dari Badan Pusat Statistik (Talaud Dalam Angka 2015), jurnal, laporan dan berbagai literatur lainnya yang relevan dengan penelitian ini dan sebagai dasar teori yang relevan dengan masalah yang diteliti.

Sedianya Penelitian ini dilakukan di 33 SKPD, namun saat penelitian berlangsung responden yang telah ditetapkan berdasarkan kriteria di 6 SKPD sedang tidak berada ditempat, maka penelitian ini hanya dilakukan di 27 SKPD (Satuan Kerja Perangkat Daerah) di Kabupaten Kepulauan Talaud selama 2 bulan dengan bantuan dan arahan dari dosen pembimbing.

Populasi dalam penelitian ini berjumlah 150 orang dimana dalam penelitian ini, seluruh populasi dijadikan sampel. Namun karena 30 responden tidak mengisi dan mengembalikan kuesioner disebabkan kesibukan responden dan ada responden yang sedang melaksanakan tugas di luar daerah sehingga jumlah sampel sebesar 120 orang.

Adapun kriteria atau karakteristik responden yang telah tentukan oleh peneliti dalam penilitian ini adalah sebagai berikut.

1. Pengguna Anggaran (PA) SKPD di Kabupaten Kepulauan Talaud;

2. Pejabat Penatausahaan Keuangan (PPK) SKPD Kabupaten Kepulauan Talaud;

3. Pejabat Pengelola Teknis Kegiatan (PPTK) SKPD Kabupaten Kepulauan Talaud;

4. Kepala Sub bidang Keuangan (KSK) SKPD Kabupaten Kepulauan Talaud;

5. Bendahara Pengeluaran (KP) SKPD Kabupaten Kepulauan Talaud.

Kuasa Bendahara Umum Daerah (BUD) dan staf bidang anggaran Dinas Pendapatan Pengelolaan Keuangan dan Aset Daerah (DPPKAD) Kabupaten Kepulauan Talaud. 


\section{Definisi Operasional Variabel dan Pengukuran Variabel}

Penelitian ini menggunakan 3 (tiga) variabel bebas/independen yaitu variabel Perencanaan, Kapasitas Sumber Daya Manusia, Komitmen Organisasi dan 1 (satu) variabel dependen yaitu Penyerapan Anggaran. Pengukuran variabel dengan menggunakan kuesioner yang berisi beberapa pertanyaan yang diukur dalam skala likert 4 poin. Berikut ini akan diuraikan konsep dan operasionalisasi masing-masing variabel.

\section{Variabel Independen}

Seperti yang telah disebutkan pada uraian sebelumnya, yang menjadi variabel independen dalam penelitian ini adalah:

\section{Perencanaan}

Perencanaan $\left(\mathrm{X}_{1}\right)$ adalah proses pendefinisian tujuan, penentuan strategi untuk mencapai tujuan tersebut, dan pengembangan serangkaian rencana komprehensif untuk menggabung dan mengkoordinasi berbagai aktivitas (Sunyoto dan Burhanudin, 2015). Perencanaan yang dimaksud dalam penelitian ini adalah proses penyusunan RKA- SKPD dasar penyusunan APBD yang selanjutnya disebut DPA-SKPD setelah APBD tersebut ditetapkan. UU No. 17 tahun 2003 tentang keuangan negara, Anggaran Pendapatan dan Belanja Daerah yang selanjutnya disebut APBD adalah rencana keuangan tahunan pemerintah daerah yang disetujui oleh DPRD. APBD ditetapkan dengan peraturan daerah.

Berdasarkan uraian tersebut maka dapat disimpulkan bahwa, dalam konteks keuangan daerah, prosedur penganggaran dan penetapan anggaran merupakan bagian yang tidak dapat dipisahkan dalam perencanaan. Itulah sebabnya dalam penelitian ini, perencanaan diukur berdasarkan prosedur penganggaran dan waktu penetapan anggaran dengan menggunakan kuesioner yang terdiri dari 6 pertanyaan dan diukur dengan skala Likert 1- 4 untuk setiap bobot pertanyaan yaitu : Tidak Benar (TB) Skor 1, Kurang Benar (KB) Skor 2, Benar (B) Skor 3, Sangat Benar (SB) Skor 4.

\section{Kapasitas Sumber Daya Manusia}

Kapasitas Sumber Daya Manusia $\left(\mathrm{X}_{2}\right)$ dalam penelitian ini tidak dibedakan dengan kompetensi. Artinya, SDM dengan kapasitas yang tinggi hanya dapat diwujudkan jika mereka memiliki kompetensi yang prima. Sebaliknya, keunggulan kompetensi akan menghasilkan profil kapasitas SDM terbaik. UU No.13 Tahun 2003 tentang ketenagakerjaan menyebutkan bahwa kompetensi kerja adalah kemampuan kerja setiap individu yang mencakup aspek pengetahuan, keterampilan, dan sikap kerja yang sesuai dengan standar yang ditetapkan. Dalam penelitian ini Kapasitas Sumber Daya Manusia diukur berdasarkan pengetahuan, keahlian yang dimiliki dan perilaku pegawai dalam melaksanakan tugas dengan menggunakan kuesioner yang terdiri dari 6 pertanyaan dan diukur denga skala Likert 1- 4 untuk setiap bobot pertanyaan yaitu : Tidak Benar (TB) Skor 1, Kurang Benar (KB) Skor 2, Benar (B) Skor 3, Sangat Benar (SB) Skor 4.

\section{Komitmen Organisasi}

Richard T. Mowday, Lyman W. Porter, \& Richard M. Steers dalam Chairy (2002) mendefinisikan komitmen organisasi $\left(\mathrm{X}_{3}\right)$ sebagai: the relative strength of an individual's identification with and involvement in a particular organization. Definisi menunjukkan bahwa komitmen organisasi memiiki arti lebih dari sekedar loyalitas yang pasif, tetapi melibatkan hubungan aktif dan keinginan karyawan untuk memberikan kontribusi yang berarti pada organisasinya. dalam penelitian ini komitmen organisasi diukur berdasarkan 3 faktor komitmen organisasi yang dikelompokkan oleh Richard M. Steers (1988) yaitu Identifikasi dengan organisasi, Keterlibatan dan Loyalitas dengan menggunakan kuesioner yang terdiri dari 6 pertanyaan dan diukur denga skala Likert 1- 4 untuk setiap bobot pertanyaan yaitu : Tidak Benar (TB) Skor 1, Kurang Benar (KB) Skor 2, Benar (B) Skor 3, Sangat Benar (SB) Skor 4. 


\section{Variabel Dependen}

Dalam penelitian ini penyerapan anggaran diukur berdasarkan tolak ukur value for money yang meliputi penilaian efisiensi, efektivitas dan ekonomis (Bastian, 2006:279) dengan menggunakan 6 pertanyaan dan diukur denga skala Likert 1- 4 untuk setiap bobot pertanyaan yaitu : Sangat Tidak Setuju (STS) Skor 1, Tidak Setuju (TS) Skor 2, Setuju (S) Skor 3, Sangat Setuju (SS) Skor 4.

\section{Pengujian Hipotesis}

Pengujian hipotesis dilakukan dengan menggunakan model analisis regresi linear berganda bertujuan untuk memprediksi berapa besar kekuatan pengaruh variabel independen terhadap variabel dependen. Persamaan rumus regresinya adalah sebagai berikut.

$$
\begin{aligned}
& \mathrm{Y}^{\prime}=\mathrm{b}_{0}+\mathrm{b}_{1} \mathrm{X}_{1}+\mathrm{b}_{2} \mathrm{X}_{2}+\mathrm{b}_{3} \mathrm{X}_{3} \\
& \text { Keterangan : } \mathrm{b}_{0}=\text { Konstanta } \\
& \mathrm{b}_{1-3}=\text { Koefisien Regresi Untuk } \mathrm{X}_{1-3} \\
& \mathrm{X}_{1}=\text { Perencanaan } \\
& \mathrm{X}_{2}=\text { Kapasitas Sumber Daya Manusia } \\
& \mathrm{X}_{3}=\text { Komitmen Organisasi } \\
& \mathrm{Y}^{\prime} \quad=\text { Penyerapan Anggaran Belanja Daerah }
\end{aligned}
$$

Sementara itu, langkah-langkah untuk menguji pengaruh variabel independen yaitu perencanaan, kapasitas sumber daya manusia, komitmen organisasi dilakukan dengan uji simultan (uji F) dan uji parsial (uji T).

\section{Hasil Penelitian}

\section{Gambaran Umum Responden}

Responden dalam penelitian ini adalah pejabat struktural dan Staf 27 SKPD (satuan kerja perangkat daerah) pemerintah Kabupaten Kepulaun Talaud yang terlibat dalam proses penyusunan anggaran dan pelaksanaan kegiatan SKPD, yang terdiri dari Pengguna Anggaran (PA), Pejabat Penatausahaan Keuangan (PPK), Pejabat Pengelola Teknis Kegiatan (PPTK), Kepala Subbidang Keuangan, Bendaharan Pengeluaran, Kuasa Bendahara Umum Daerah (Kuasa BUD) dan staf bidang anggaran DPPKAD Kabupaten Kepulauan Talaud. Kuesioner yang disebarkan sebanyak 150 eksemplar namun kuesioner yang kembali hanya sebanyak 120 eksemplar.

\section{Analisis Regresi Linear Berganda}

Tabel 1 Regresi Linear Berganda

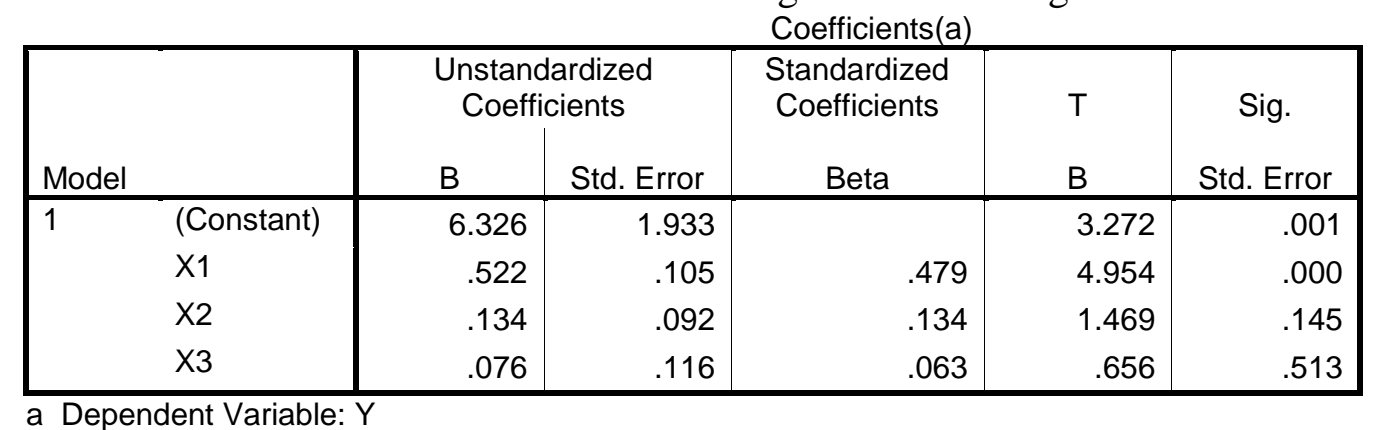

Berdasarkan Tabel 1 diperoleh model Analisis Regresi Linear Berganda dalam penelitian ini adalah:

$$
Y=6,326+0,522 X_{1}+0,134 X_{2}+0,076 X_{3}
$$

Berdasarkan model analisis diatas diperoleh nilai konstanta positif (+). Nilai konstanta positif menunjukkan bahwa variabel independen $\mathrm{X}_{1}, \mathrm{X}_{2}$, dan $\mathrm{X}_{3}$ (Perencanaan, 
Kapasitas Sumber Daya Manusia, dan Komitmen Organsiasi) berpengaruh positif terhadap variabel dependen Penyerapan Anggaran Belanja Daerah (Y) namun berbeda signifikasinya. Sehingga Bila variabel independen meningkat dalam kurun waktu 1 tahun, maka besarnya tingkat penyerapan anggaran belanja daerah pada pemerintah kabupaten kepulauan talaud akan meningkat pula.

Selanjutnya nilai $b_{1}$ yang merupakan koefisien regresi dari variabel $X_{1}$ (Perencanaan) terhadap variabel Y (Penyerapan Anggaran Belanja Daerah) positif (+) berarti antara Perencanaan $\left(\mathrm{X}_{1}\right)$ dan Penyerapan Anggaran Belanja Daerah (Y) berhubungan positif (searah) atau dengan kata lain semakin baik perencanaan anggaran maka akan semakin baik pula tingkat penyerapan anggaran belanja daerah.

Nilai $b_{2}$ merupakan koefisien regresi dari variabel $\mathrm{X}_{2}$ (Kapasitas Sumber Daya Manusia) terhadap variabel Y (Penyerapan Anggaran Belanja Daerah) bernilai positif (+) artinya antara Kapasitas Sumber Daya Manusia $\left(\mathrm{X}_{2}\right)$ dan Penyerapan Anggaran Belanja Daerah (Y) berhubungan positif (searah) sehingga dapat dikatakan bahwa semakin baik kapasitas sumber daya manusia maka akan semakin baik pula tingkat penyerapan anggaran belanja daerah.

Sedangkan nilai $b_{3}$ yang merupakan koefisien regresi dari variabel $X_{3}$ (Komitmen Organisasi) bernilai positif $(+)$ berarti antara Komitmen Organisasi $\left(\mathrm{X}_{3}\right)$ dan Penyerapan Anggaran Belanja Daerah (Y) berhubungan positif (searah) atau dengan kata lain bahwa semakin tinggi komitmen organisasi maka semakin baik pula tingkat penyerapan anggaran.

Berdasarkan nilai koefisien regresi dapat diketahui bahwa ternyata faktor perencanaan lebih dominan atau signifikan berpengaruh terhadap tingkat penyerapan anggaran belanja daerah pada Pemerintah Kabupaten Kepulauan Talaud.

\section{Uji Parsial (Uji t)}

Berdasarkan pengambilan keputusan mengenai penerimaan dan penolakan hipotesis, dapat disimpulkan bahwa:

1. Nilai $t_{\text {hitung }} X_{1}=4,954>1,981$ dan nilai signifikasi< 0,05 maka dapat disimpulkan Hipotesis $\left(\mathrm{H}_{1}\right)$ yang menyatakan bahwa variabel independen Perencanaan $\left(\mathrm{X}_{1}\right)$ berpengaruh signifikan terhadap variabel dependen Penyerapan Anggaran Belanja Daerah (Y) diterima, dengan demikian $\mathrm{H}_{0}$ ditolak. Artinya, Perencanaan berpengaruh singnifikan terhadap Penyerapan Anggaran Belanja Daerah Pemerintah Kabupaten Kepulauan Talaud.

2. Nilai $t_{\text {hitung }} X_{2}=1,469<1,981$ dan nilai signifikasi $>0,05$ maka dapat disimpulkan Hipotesis $\left(\mathrm{H}_{2}\right)$ yang menyatakan bahwa variabel Kapasitaas Sumber Daya Manusia $\left(\mathrm{X}_{2}\right)$ berpengaruh signifikan terhadap variabel Penyerapan Anggaran Belanja Daerah (Y) ditolak, dengan demikian $\mathrm{H}_{0}$ diterima. Artinya, Kapasitas Sumber Daya Manusia tidak berpengaruh signifikan terhadap Penyerapan Anggaran Belanja Daerah Pemerintah Kabupaten Kepulauan Talaud.

3. Nilai $t_{\text {hitung }} \mathrm{X}_{3}=0,656<1,981$ dan nilai signifikasi $>0,05$ maka dapat disimpulkan Hipotesis $\left(\mathrm{H}_{3}\right)$ yang menyatakan bahwa variabel Komitmen Organisasi $\left(\mathrm{X}_{3}\right)$ secara parsial berpengaruh signifikan terhadap variabel Penyerapan Anggaran Belanja Daerah (Y) ditolak, dengan demikian $\mathrm{H}_{0}$ diterima. Artinya, Komitmen Organisasi tidak berpengaruh signifikan terhadap Penyerapan Anggaran Belanja Daerah Pemerintah Kabupaten Kepulauan Talaud.

Meski demikian berdasarkan kriteria penentuan hipotesis nol dan hipotesis alterhatif yang telah dibahas pada bab IV tesis ini, dapat disimpulkan bahwa secara parsial variabel independen Perencanaan $\left(\mathrm{X}_{1}\right)$, Kapasitas Sumber Daya Manusia $\left(\mathrm{X}_{2}\right)$ dan Komitmen Organisasi $\left(\mathrm{X}_{3}\right)$ berpengaruh terhadap variabel Penyerapan Anggaran Belanja Daerah (Y) Pada Pemerintah kabupaten Kepulauan Talaud meski berbeda signifikasinya. 


\section{KESIMPULAN}

Penelitian ini meneliti pengaruh Perencanaan, Kapasitas Sumber Daya Manusia dan Komitmen Organisasi terhadap Penyerapan Anggaran Belanja Daerah pada Pemerintah Kabupaten Kepulauan Talaud. Dari hasil penelitian dan analisis data dalam penelitian ini, maka dapat diambil kesimpulan sebagai berikut.

1. Perencanaan berpengaruh signifikan terhadap penyerapan Anggaran Belanja Daerah Kabupaten Kepulauan Talaud. Selain itu hasil analisis regresi juga menunjukkan bahwa perencanaan berpengaruh positif terhadap penyerapan anggaran belanja daerah. Dengan demikian hal ini berarti bahwa seharusnya dengan perencanaan anggaran yang baik dapat menghasilkan penyerapan anggaran belanja daerah yang semakin baik pula.

2. Kapasitas Sumber Daya Manusia berpengaruh positif (+) namun tidak signifikan terhadap Penyerapan Anggaran Belanja Daerah. Berdasarkan hasil penelitian yang dilakukan oleh penulis, hal ini disebabkan oleh penempatan tugas yang tidak sesuai dengan latar belakang pendidikan yang disertai masih minimnya pelatihan dan bimbingan teknis mengenai pengelolaan keuangan serta tingginya frekuensi mutasi pengawai sehingga pegawai bersangkutan masih harus menyesuaikan diri dengan tugas yang baru. Nilai koefisien regresi positif (+) menunjukkan adanya hubungan searah antara sumber daya manusia dengan penyerapan anggaran belanja daerah, yang berarti bahwa dengan meningkatnya kapasitas sumber daya manusia maka akan meningkatkan kemampuan penyerapan anggaran belanja daerah.

3. Komitmen Organisasi berpengaruh positif (+) namun tidak signifikan terhadap Penyerapan Anggaran Belanja Daerah. Berdasarkan hasil penelitian, minimnya pengawasan yang dilakukan oleh pimpinan SKPD dalam pelaksanaan kegiatan dan anggaran, dan pelaksanaan kegiatan yang tidak sesuai perencanaan menjadi gambaran masih minimnya komitmen organisasi yang pada akhirnya berpengaruh terhadap tingkat penyerapan anggaran. Nilai koefisien regresi positif (+) menunjukkan adanya hubungan searah antara komitmen organisasi dengan penyerapan anggaran belanja daerah, yang berarti bahwa dengan meningkatnya kapasitas sumber daya manusia maka akan meningkatkan kemampuan penyerapan anggaran belanja daerah.

4. Hasil Uji F menunjukkan bahwa Perencanaan, Kapasitas Sumber Daya Manusia, Dan Komitmen Organisasi secara bersama-sama berpengaruh terhadap Penyerapan Anggaran Belanja Daerah Pada Pemerintah Kabupaten Kepulauan Talaud. Hal yang sama ditunjukkan oleh hasil uji Koefisien Korelasi dan Koefisien Determinasi, dimana menunjukkan bahwa terjadi hubungan yang kuat antara Perencanaan, Kapasitas Sumber Daya Manusia dan Komitmen Organisasi terhadap Penyerapan Anggaran Belanja Daerah Pada Pemerintah kabupaten Kepulauan Talaud. Sehingga peningkatan Kapasitas Sumber Daya Manusia dan Komitmen Organisasi sangat dibutuhkan jika kita ingin meningkatakan Penyerapan Anggaran Belanja Daerah Pada Pemerintah Kabupaten Kepulauan Talaud.

\section{SARAN}

Untuk penelitian selanjutnya, penulis memberikan saran sebagai berikut.

1. Peneliti selanjutnya dapat mempertimbangkan menggunakan metode metode campuran (mix method) kuantitatif dan kualitatif dalam penelitian, dimana metode kualitatif digunakan untuk menjelaskan hasil yang diperoleh dari metode kuantitatif sehingga dapat memperoleh kesimpulan yang sesuai dengan kondisi sebenarnya.

2. Mempertimbangkan untuk lebih mendalami dan fokus pada satu tahun anggaran.

3. Peneliti selanjutnya diharapkan dapat menambah variabel dan mengembangkan kuesioner lebih lanjut sehingga mampu mengungkap variabel lain yang 
mempengaruhi tingkat penyerapan anggaran belanja di Kabupaten Kepulauan Talaud atau di daerah yang lain yang diteliti.

\section{DAFTAR PUSTAKA}

Arif, Emkhad. 2012. Identifikasi Faktor-Faktor Penyebab Minimnya Penyerapan Anggaran Pendapatan dan Belanja Daerah (APBD) Kabupaten/Kota di Provinsi Riau Tahun 2011. Tesis. Riau: Universitas Islam Riau.

Bastian, Indra. 2006. Akuntansi Sektor Publik. Jakarta: Penerbit Erlangga.

Badura, Albert. 1971. Social Learning Theory. Library Of Congress Catalog. United States Of America. Stanford University.

Chairy S. Liche. 2002. Seputar Komitmen Organisasi. Jurnal UI. Jakarta. Universitas Indonesia.

Juliani, Dian. 2014. Pengaruh faktor-faktor kontekstual terhadap Persepsian penyerapan anggaran terkait pengadaan Barang/jasa. Skripsi. Yogyakarta: Fakultas Ekonomi Universitas Gadjah Mada.

Kuncoro, D. Egiastyo. 2013. Analisis Penyerapan Anggaran Pasca Penerapan Aplikasi SiPP Pada Satker Pelaksanaan Jalan Nasional Wil.I Dinas PU Prov. Kaltim. Sripsi. Samarinda: Fakultas Ilmu Sosial dan Ilmu Politik Universitas Mulawarman.

Mathis, L. Robert and J. H. Jackson. 2010. Human Resorce Management. Vol. 13. South Western Cengage Learning.

Nugroho, Budi. 2015. Mengenal Lebih Dekat Konsep Anggaran Daerah. https://konsultankti.wordpress.com/2015. Diakses tanggal 22 September 2016.

Priatno, A. Prasetyo. 2013. Analisis Faktor-Faktor Yang Mempengaruhi Penyerapan Anggaran Pada Satuan Kerja Lingkup Pembayaran KPPN Blitar. Skripsi. Malang: Fakultas Ekonomi dan Bisnis Universitas Brawijaya.

Raharjo, Eko. Teori Agensi Dan Teori Stewarship Dalam Perspektif Akuntansi. Jurnal Ekonomi. Semarang. STIE Pelita Nusantara Semarang.

Rothich, K. Charles. 2015. Factors Affecting Budget Utilization KerichoCounty Government In Kenya. International Journal Of Economics, Commerce and Mangement. Kenya. Jomo Kenyatta University Of Agriculture and Teknologi.

Rumenser, Peggy. 2014. Pengaruh Komitmen, Kualitas Sumber Daya Manusia, Gaya Kepemimpinan Terhadap Kemampuan Penyusunan Anggaran Pada Pemerintah Kota Manado. Manado. Fakultas Ekonomi Univeritas Sam Ratulangi.

Sugiyoni. 2008. Metodologi Penelitian Kuantitatif. Cetakan ke 4. Bandung: Penerbit Alfabeta

Sunyoto, Danang dan Burhanudin. 2015. Teori Perilaku Keorganisasian. Jakarta: Penerbit CAPS (Center Of Academic Publishing Service).

Ulfa, Rusda. 2013. Faktor-Faktor Yang Mempengaruhi Penyerapan Anggaran Di Pemda DKI Jakarta (Studi Kasus: Sekretariat DPRD DKI Jakarta Untuk T.A 2010 dan 2011. Sripsi. Jakarta. Fakultas Ekonomi Universitas Indonesia

Zarinah, Monik. 2015. Pengaruh Perencanaan Anggaran dan Kualitas Sumber Daya Manusia Terhadap Tingkat Penyerapan Anggaran Satuan Kerja Perangkat Daerah Di Kabupaten Aceh Utara. Tesis. Banda Aceh. Pascasarjana Prodi Magister Akuntansi Universitas Syiah Kuala, Darussalam. 